\title{
Effects of Some Middle East Crude Oils-brine-rock Interactions on Wettability
}

\author{
M. H. SayyouH* and M. Al-Blehed \\ Petroleum Engineering Dept., King Saud University, \\ P.O. Box 800, Riyadh 11421, Kingdom of Saudi Arabia
}

(Received January 8, 1990)

\begin{abstract}
The main objective of this research was to study the alteration of wettability of a Saudi sandstone using five different Saudi crude oils (Safaniyah crude, Abu Safah crude, heavy, medium, and light crudes). The acidity of these crude oils was determined and the effect of acidity, alkalinity, and temperature on wettability were investigated.

It was found that contact angle increased with increasing Saudi crude oil acidity at both 22 and $50^{\circ} \mathrm{C}$ for all $\mathrm{NaOH}$ concentrations used. The contact angle tends to show a minimum with increasing $\mathrm{pH}$ at $22^{\circ} \mathrm{C}$. However, this minimum disappeared at $50^{\circ} \mathrm{C}$ for all $\mathrm{pH}$ values of the aqueous phase used. The Saudi crude oil/brine/rock system was found to be more oil-wet at $50^{\circ} \mathrm{C}$ than at $22^{\circ} \mathrm{C}$. The contact angle increased with increasing temperature from 22 to $50^{\circ} \mathrm{C}$.
\end{abstract}

\section{Introduction}

Surface and capillary effects are among the factors that play an important role in the movement of oil, water, and gas through an oil reservoir. Surface effects include: (i) phenomena occurring at the boundary between any two phases during adsorption, and a change of rheological and thermodynamic properties of the surface layer (ii) phenomena associated with the formation of polymolecular liquid layers possessing anomolous mechanical and thermodynamic properties near the interface between two phases. Capillary effects include all phenomena due to the presence of curved surface boundaries at the interface between two phases.

The wettability of reservoir rock can be altered by the adsorption of polar organic compounds and/or deposition of organic material that was originally in the crude oil. The degree of alteration is found by the interaction of the oil constituents with the mineral surface and the chemical constituents of the brine including $\mathrm{pH}^{1}$.

The surface active components of crude oil are believed to be polar organic compounds that contain mainly nitrogen, sulfur and oxygen (NSO compounds). The oxygen compounds are usually acidic. It was found that carboxylic acids are interfacially active when the $\mathrm{pH}$ is high ${ }^{1), 2}$.

Because the surface active components in crude oil are composed of a large number of very com-

\footnotetext{
* To whom correspondence should be addressed.
}

plex chemicals, it has not been possible to identify the compounds that alter wettability ${ }^{3)}$ ). A laboratory study showed that asphaltenes in some crude oils are responsible for wettability alteration from water-wet to oil-wet ${ }^{1}$.

The salinity and $\mathrm{pH}$ of brine are very important in determining wettability because they strongly affect the surface charge on the rock and fluid interfaces ${ }^{1)}$. Silica surface exhibit a partial negative charge because of the strong negativity of the oxygen atoms. Limestone and dolomite surfaces exhibit positive charges due to hydrolysis of the carbonate. Because the major portion of the polar organic compounds in crude oils is acidic, they are normally repelled from the silica surface and attracted to the limestone/dolomite surfaces ${ }^{7}$.

In a previous study carried out by Sayyouh et al.8), it was found that the contact angle increased with increasing clay content of sandstone when 0 and 35,000 ppm $\mathrm{NaCl}$ solutions were used. The presence of alkaline in a saline solution made the system preferentially oil-wet. The same study also showed that no effect of clay content on contact angle was observed in the presence of polymers. The polymers adsorb and coat the surfaces of the clays thus neutralizing clays effects ${ }^{8)}$.

Several papers have recently been published reviewing the effect of wettability on electrical properties, capillary pressure, relative permeability of the porous medium, and waterflooding ${ }^{9) \sim 13)}$.

A procedure for restoring original rock surface properties was described by Cuiec et al. ${ }^{14)}$. Two other papers by the same author presented an 
attempt to understand the rock/crude-oil interactions and wettability and the necessity of respecting reservoir conditions in displacement tests ${ }^{15)}, 16$ ). No correlation was found between wettability and various characteristics; but some correlation was found between sulfur content,-asphaltenes and wettability ${ }^{16)}$.

McCoffery ${ }^{17)}$ measured the water advancing contact angle on quartz $n$-tetradecane and brine. The contact angle was about $40^{\circ}$ at $25^{\circ} \mathrm{C}$, but decreased to about $15^{\circ}$ as the temperature was raised to $150^{\circ} \mathrm{C}$.

\section{Experimental Work}

The sandstone cores were obtained from wells in the Aramco production area in the Eastern part of the Kingdom. The procedures of cleaning reservoir core samples presented by Cuiec ${ }^{14), 15)}$ were used in this study. The composition of the sandstone cores is shown in Table 1.

The acid number of different crude oils was determined using an ASTM procedure ${ }^{18)}$. Solvent mixture and crude oil sample were titrated with potassium hydroxide $(\mathrm{KOH})$. The titrant volumes were plotted against the measured millivolts of the mixture, and the upper and lower peaks were determined. The average acid number (mg $\mathrm{KOH} / \mathrm{gm}$ crude) of the five crude oils were then determined. The general characteristics and properties of the five crude oils are presented in Table 2.

The aqueous solutions were: (1) distilled water, (2) 35,000 ppm NaCl, (3) $0.5 \%$ (by weight) $\mathrm{NaOH}$ in $35,000 \mathrm{ppm} \mathrm{NaCl}$, and (4) $1.0 \%$ (by weight) $\mathrm{NaOH}$ in 35,000 ppm NaCl.

There are three accredited ways which are extensively used in the oil industry for measuring the

Table 1 Mineralogical Composition of Sandstone Cores

\begin{tabular}{cccc}
\hline $\begin{array}{c}\text { Quartz } \\
{[\mathrm{wt} \%]}\end{array}$ & $\begin{array}{c}\text { Feldspar } \\
{[\mathrm{wt} \%]}\end{array}$ & $\begin{array}{c}\text { Other minerals } \\
{[\mathrm{wt} \%]}\end{array}$ & $\begin{array}{c}\text { Clays* } \\
{[\mathrm{wt} \%]}\end{array}$ \\
\hline 85 & 3 & 4 & 8 \\
\hline$*$ Contain & $40 \%$ kaolinite, & $27 \%$ & chlorite, $17 \%$ illite, and $6 \%$ \\
montmorillonite.
\end{tabular}

wettability of a rock/brine/oil system. These are the Amott method, the USBM method and the Contact angle method ${ }^{8}$. While the Amott and USBM methods use actual core samples, the contact angle method fits best for pure fluids and mineral crystals that represent reservoir cores. Where actual cores are used, there could be a wide range of contact angles due to the sharp edges of the grain structure, and very long times are needed to reach equilibrium contact angles.

The surface properties of sandstone may be greatly modified by contact with crude oil under reservoir conditions. The change produced depends on the crude oil and it may go all the way to reversing the wettability in the case of a crude oil rich in polar products ${ }^{14}$.

The wettability measurements were made using the contact angle method ${ }^{19)}$. Figure 1 shows a schematic diagram of the apparatus used in measuring the contact angle between crude oil and aqueous solution. A camera was used to take picture of the oil droplet. The oil droplet was placed on the bottom of a highly smoothed surface of a sandstone sample immersed in the aqueous solution (Fig. 2). The equilibrated contact angles were then measured from the photographs. All measurements were carried out at both $22^{\circ} \mathrm{C}$ (laboratory temperature) and at $50^{\circ} \mathrm{C}$. Each contact angle at any time is measured more than four times under the same experimental conditions,

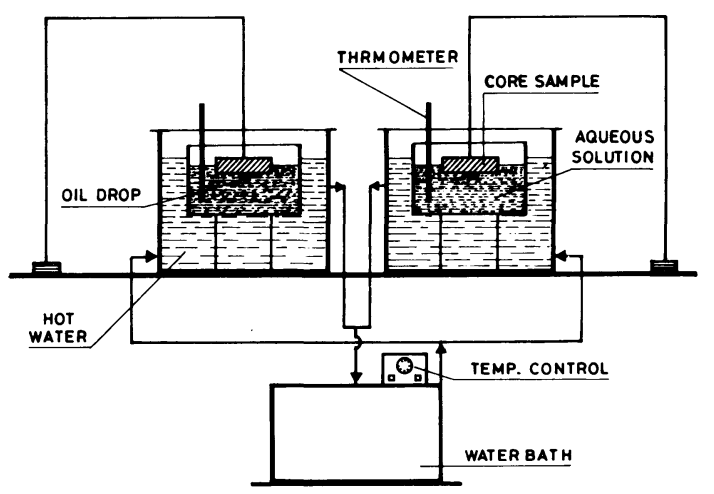

Fig. 1 Contact Angle Measurement Apparatus

Table 2 Physical Properties of Different Crude Oils

\begin{tabular}{|c|c|c|c|c|c|c|c|c|c|c|}
\hline \multirow{2}{*}{$\begin{array}{c}\text { Crude oil } \\
\text { (from Saudi fields) }\end{array}$} & \multirow{2}{*}{$\begin{array}{c}\text { Acidic } \\
\text { number }\end{array}$} & \multirow{2}{*}{$\begin{array}{l}\text { Specific } \\
\text { gravity }\end{array}$} & \multirow{2}{*}{$\begin{array}{c}\text { Surface } \\
\text { tension } \\
{[\text { dyne } / \mathrm{cm})}\end{array}$} & \multirow{2}{*}{ API } & \multirow{2}{*}{$\begin{array}{c}\text { Flash point } \\
\text { temperature } \\
{\left[{ }^{\circ} \mathrm{C}\right]}\end{array}$} & \multirow{2}{*}{$\begin{array}{l}\text { Pour } \\
\text { point } \\
{\left[{ }^{\circ} \mathrm{C}\right]}\end{array}$} & \multirow{2}{*}{$\begin{array}{l}\text { Cloud } \\
\text { point } \\
{\left[{ }^{\circ} \mathrm{C}\right]}\end{array}$} & \multicolumn{3}{|c|}{$\begin{array}{l}\text { Separated volume under } \\
\text { vacuum distillation [\%] }\end{array}$} \\
\hline & & & & & & & & Gas oil & $\begin{array}{c}\text { Wax } \\
\text { distillate }\end{array}$ & Bottoms \\
\hline Heavy & 1.0 & 0.885 & 30.4 & 28.200 & 23 & -3 & 0 & 8.4 & 16.6 & 75.0 \\
\hline Light & 0.57 & 0.850 & 28.8 & 34.970 & 18 & -22 & -16 & 15.4 & 5.6 & 81.0 \\
\hline Safaniyah & 1.4 & 0.860 & 28.1 & 33.030 & 20 & -2 & 2 & - & 8.6 & 91.4 \\
\hline Abu-Safah & 0.5 & 0.855 & 28.7 & 33.970 & 21 & -4 & 2 & 7.0 & 12.6 & 80.4 \\
\hline Medium & 0.6 & 0.870 & 27.6 & 31.143 & 19 & -25 & -17 & 6.0 & 10.0 & 84.0 \\
\hline
\end{tabular}


Table 3 Reservoir Data of Different Crude Oils

\begin{tabular}{|c|c|c|c|c|c|c|c|c|c|c|}
\hline Crude oil & $\begin{array}{l}\text { Original } \\
\text { pressure } \\
\text { [PSIG] }\end{array}$ & $\begin{array}{l}\text { Depth } \\
\text { [FT] }\end{array}$ & $\begin{array}{c}\text { Temper- } \\
\text { ature } \\
{\left[{ }^{\circ} \mathrm{C}\right]}\end{array}$ & $\begin{array}{c}\text { Saturation } \\
\text { pressure } \\
\text { [PSIA] }\end{array}$ & $\begin{array}{c}\text { Formati } \\
\text { Solution } \\
\text { GOR } \\
\text { [SCF/STB] }\end{array}$ & $\begin{array}{l}\text { Sulfur } \\
\text { Volume } \\
\text { factor } \\
\text { [RB/STB] }\end{array}$ & $\begin{array}{c}\text { Weighted } \\
\text { avg. }\end{array}$ & $\begin{array}{l}\text { Permea- } \\
\text { bility } \\
\text { [md] }\end{array}$ & $\begin{array}{c}\text { Rock } \\
\text { porosity } \\
{[\%]}\end{array}$ & $\begin{array}{c}\text { Connate } \\
\text { saturation } \\
\text { [fraction] }\end{array}$ \\
\hline Abu-Safah & 3,250 & 6,535 & 90 & 305 & 100 & 1.0730 & 2.7 & 440 & 24.4 & 0.136 \\
\hline Light & 3,627 & 7,300 & 103 & 411 & 150 & 1.143 & 1.9 & 268 & 19.0 & 0.14 \\
\hline Medium & 3,635 & 7,300 & 103 & 411 & 139 & 1.33 & 2.0 & 776 & 26.0 & 0.14 \\
\hline Heavy & 3,624 & 7,300 & 104 & 423 & 150 & 1.141 & 2.2 & 180 & 21.0 & 0.20 \\
\hline Safaniyah & 2,640 & 5,275 & 71 & 566 & 132 & 1.1 & 2.9 & 3,800 & 26.0 & 0.12 \\
\hline
\end{tabular}

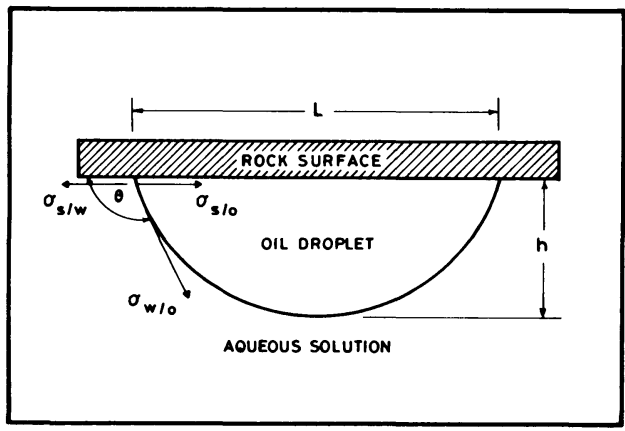

Fig. 2 Oil Droplet Dimensions

and the average value of these measurements is reportd. Different sandstone samples, from the same area having the same composition presented in Table 1, were used for each crude oil.

\section{Results and Discussion}

To investigate the effect of Saudi crude oil/ brine/rock interactions on wettability, sandstone samples and five different Saudi crude oils were used for measuring the contact angles of the oil/ water interface within rock surface. All measurements were conducted under the same conditions. All aqueous solutions were prepared just before use.

Figures 3 through 6 represent the results of contact angle measurements for different crude oils (Abu-Safah, light, medium, heavy, and Safaniyah crudes) using distilled water, $0,0.5$, and $1 \% \mathrm{NaOH}$ in $35,000 \mathrm{ppm} \mathrm{NaCl}$ solution at $22^{\circ} \mathrm{C}$. The contact angle attained equilibrium after about 20 hours for all crudes. When Abu-Safah crude oil and $35,000 \mathrm{ppm} \mathrm{NaCl}$ was used, the rock surface was water-wet; however, the rock sample was oil-wet when the other crude oils and the same aqueous solution were used as shown in Fig. 4. With $0.5 \%$ $\mathrm{NaOH}$ in $35,000 \mathrm{ppm} \mathrm{NaCl}$, the rock surface was oil-wet for all crude oils tested as shown in Fig. 5. Figure 5 also indicates that using Safaniyah and heavy crude oil resulted in contact angles of almost 180 degrees. Figure 6 shows that increasing $\mathrm{NaOH}$ concentration to $1 \%$ resulted in an increase in the contact angle to almost 180 degrees for all

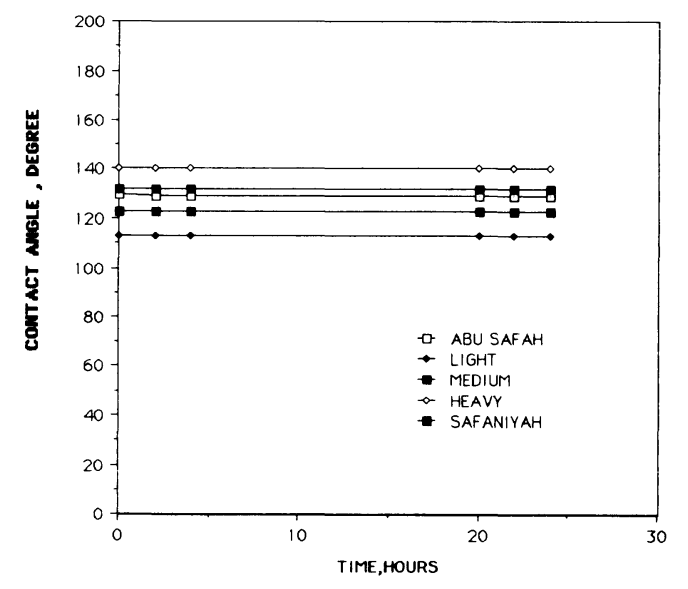

Fig. 3 Contact Angle vs. Time for Saudi Crude Oils in Distilled Water at $22^{\circ} \mathrm{C}$

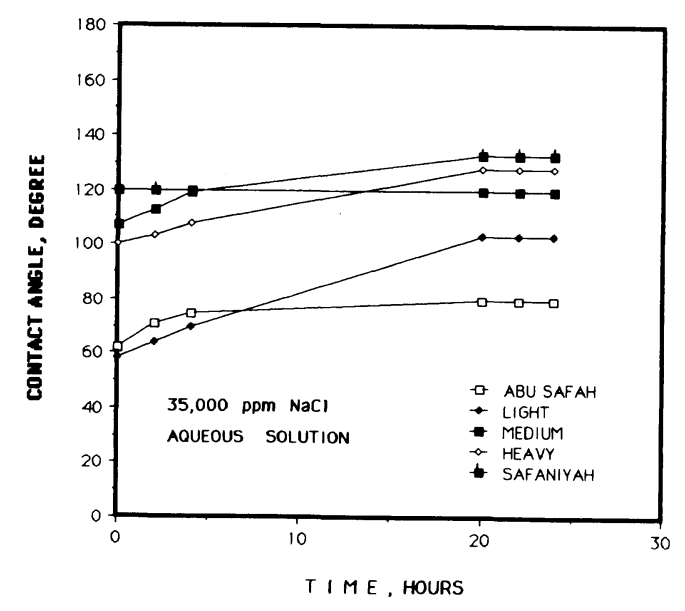

Fig. 4 Contact Angle vs. Time for Saudi Crude Oils at $22^{\circ} \mathrm{C}$

crude oils except Abu-Safah.

Figures 7 through 10 show the results of contact angle measurements for the crude oils and distilled water, $0,0.5$, and $1 \% \mathrm{NaOH}$ in $35,000 \mathrm{ppm} \mathrm{NaCl}$ at $50^{\circ} \mathrm{C}$. The results were similar to those obtained at $22^{\circ} \mathrm{C}$.

The equilibrium time for contact angle at $50^{\circ} \mathrm{C}$ was less than that required for attainment of equilibrium at $22^{\circ} \mathrm{C}$. Equilibrium was attained after only 2 hours. The most important observation 


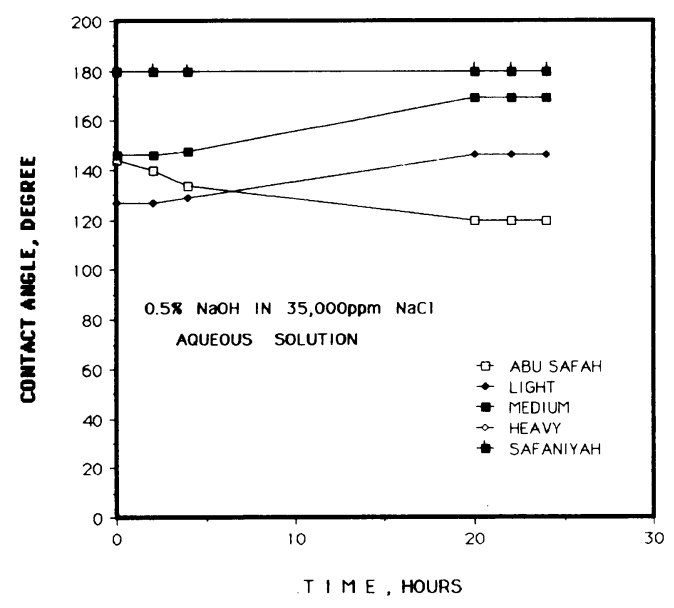

Fig. 5 Contact Angle vs. Time for Saudi Crude Oils at $22^{\circ} \mathrm{C}$

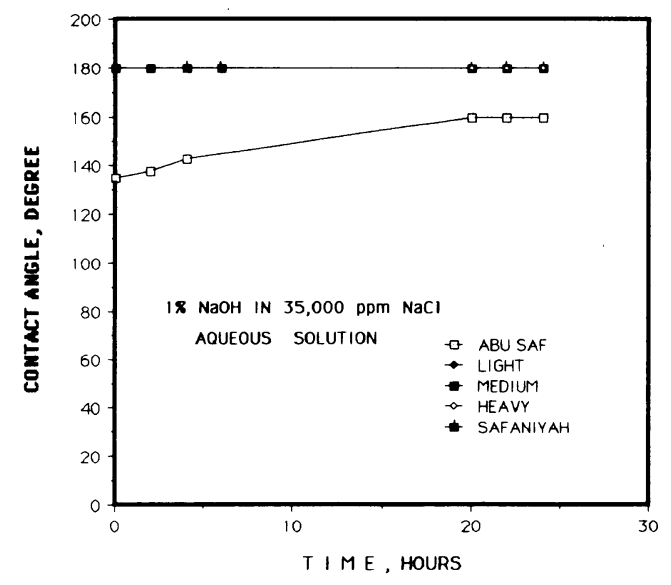

Fig. 6 Contact Angle vs. Time for Saudi Crude Oils at $22^{\circ} \mathrm{C}$

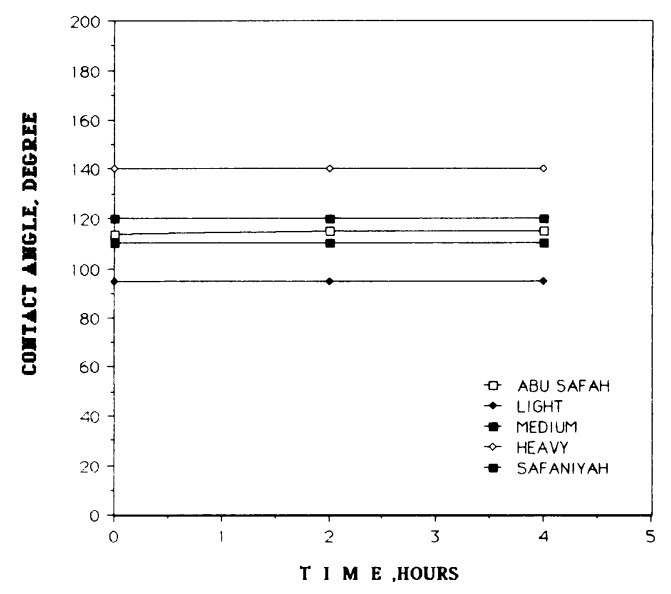

Fig. 7 Contact Angle vs. Time for Saudi Crude Oils in Distilled Water at $50^{\circ} \mathrm{C}$

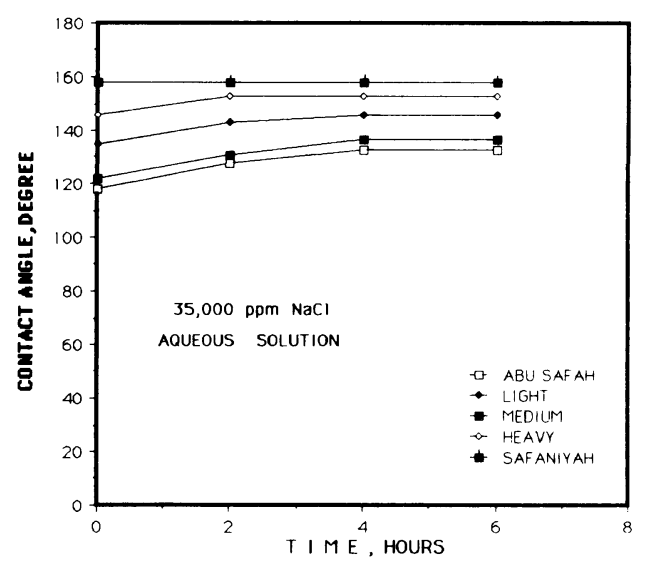

Fig. 8 Contact Angle vs. Time for Saudi Crude Oils at $50^{\circ} \mathrm{C}$

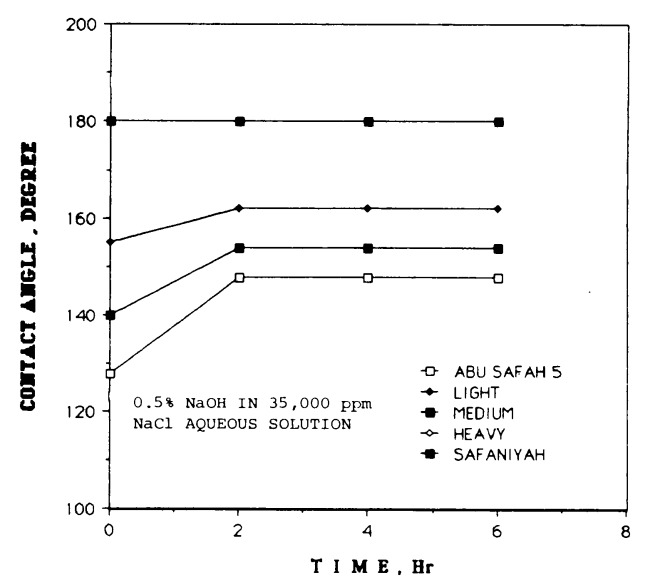

Fig. 9 Contact Angle vs. Time for Different Crudes Using $0.5 \% \mathrm{NaOH}$ in $35,000 \mathrm{ppm} \mathrm{NaCl}$ at $50^{\circ} \mathrm{C}$

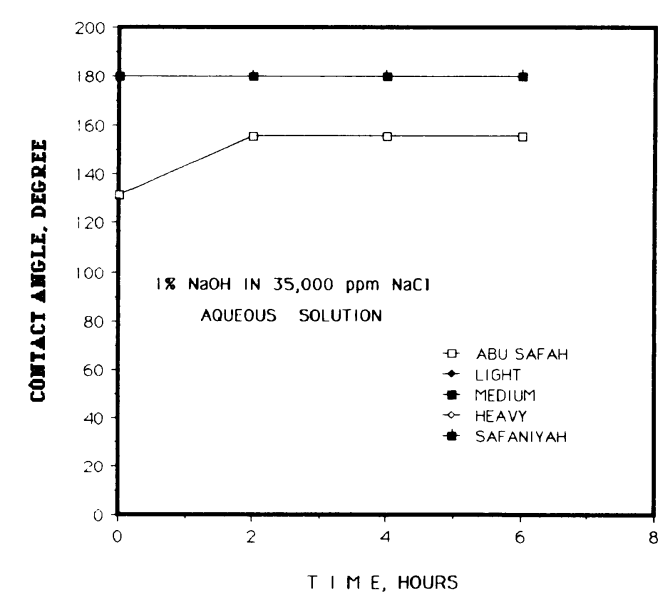

Fig. 10 Contact Angle vs. Time for Saudi Crude Oils at $50^{\circ} \mathrm{C}$ 
was that the contact angles were greater at the higher temperature, $50^{\circ} \mathrm{C}$, when using $\mathrm{NaCl}$ and $\mathrm{NaOH}$ solutions.

\section{1 Effect of Crude Oil Acidity on Contact Angle}

Figure 11 shows the variation of contact angle with respect to the acid number of the crude oils tested in this investigation. The high acidity crude oil made the core oil-wet. A small increase in acid number (from 0.4 to 0.5 ) caused a sharp increase in the contact angle. Acid numbers greater than 0.6 , caused gradual changes in contact angle for all $\mathrm{NaOH}$ concentrations (0.0, 0.5 and $1 \%)$ as shown in Fig. 11. The same behavior was observed at $50^{\circ} \mathrm{C}$ as shown in Fig. 12. This effect has not yet been reported in the literature.

Although the natural surface-active materials of crude oils are found in a wide range of petroleum fractions, they are more prevailant in the heavier fractions of crude ${ }^{1)}$. Figures 11 and 12 indicate

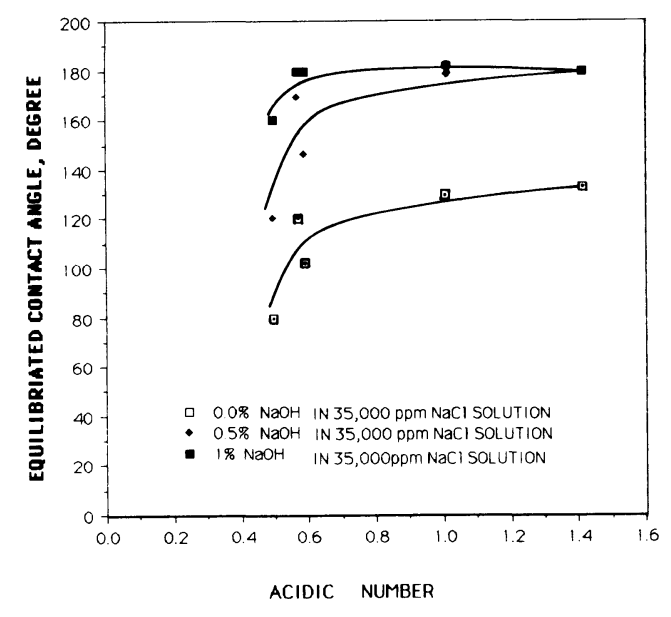

Fig. 11 Effect of Acidic Number on Contact Angle Using $0,0.5$, and $1 \% \mathrm{NaOH}$ at $22^{\circ} \mathrm{C}$

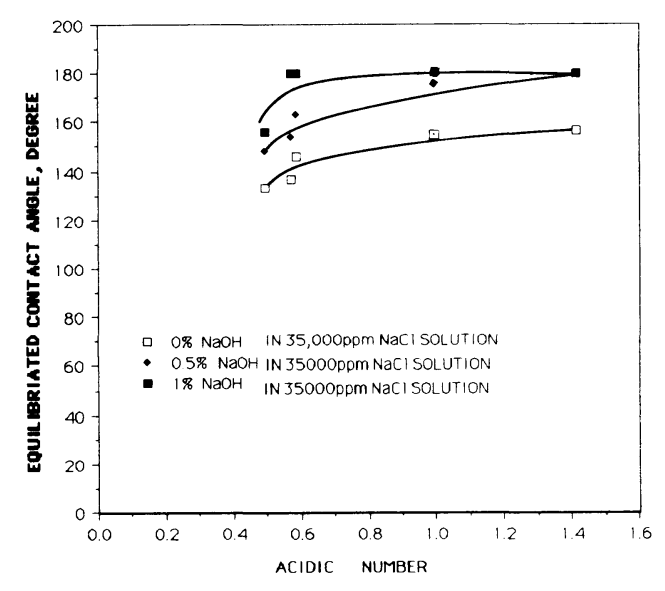

Fig. 12 Effect of Crude Acidic Number Contact Angle Using $0,0.5$, and $1 \% \mathrm{NaOH}$ at $50^{\circ} \mathrm{C}$ that contact angle was affected by the acidity of the crude oils; however, because the surfactants in the crude oils are composed of a large number of complex compounds, their chemical structure has not yet been completely elucidated. The aromatic compounds with acidic functional groups react and adsorb on the rock surface and these alter wettability.

\section{2 Effect of pH on Contact Angle}

The $\mathrm{pH}$ of aqueous solutions is an important factor affecting wettability because it strongly affects the surface charge of the rock and fluid interfaces. Figures 13 and 14 show the effect of $\mathrm{pH}$ on the contact angle measurements at 22 and $50^{\circ} \mathrm{C}$, respectively.

The contact angle decreases with increasing $\mathrm{pH}$, up to $\mathrm{pH} \mathrm{10,} \mathrm{and} \mathrm{thereafter} \mathrm{it} \mathrm{showed} \mathrm{an} \mathrm{increase}$ with further increase in $\mathrm{pH}$ for the crude oils used at $22^{\circ} \mathrm{C}$ (Fig. 13).

The surface forces in a solid-water-oil system (Fig. 2) are related by the well-known Young's Dupre equation as follows:

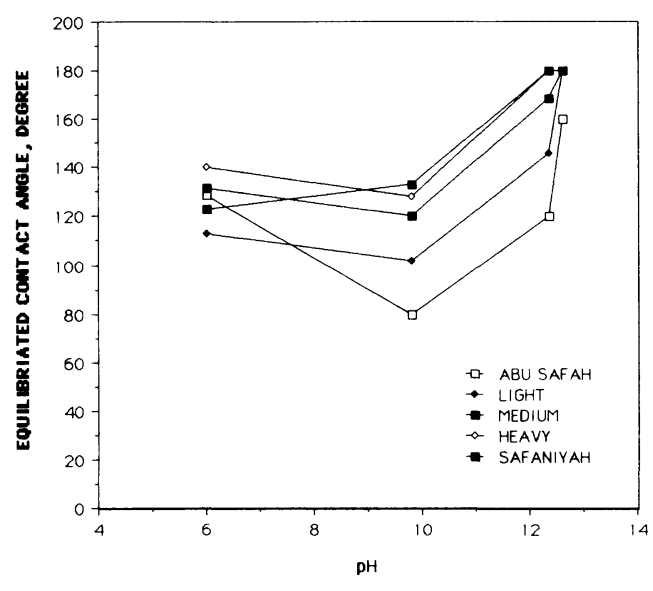

Fig. 13 Effect of $\mathrm{pH}$ on Contact Angle at $22^{\circ} \mathrm{C}$

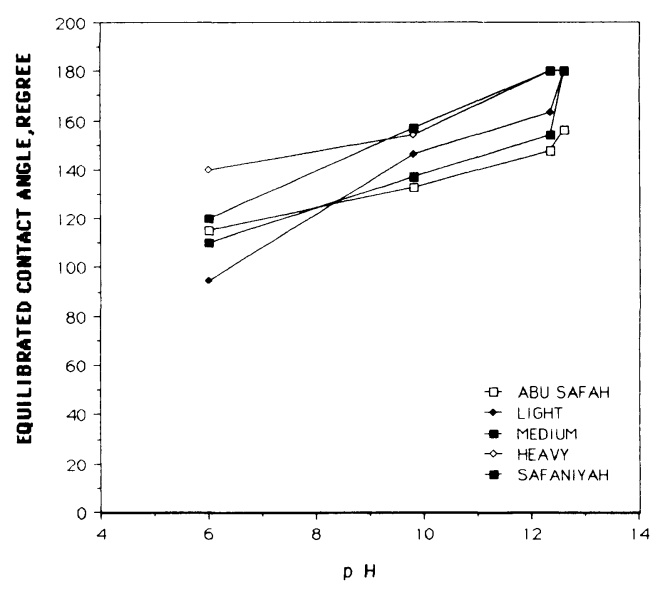

Fig. 14 Effect of $\mathrm{pH}$ on Contact Angle at $50^{\circ} \mathrm{C}$ 


$$
\sigma_{\mathrm{S} / \mathrm{O}}-\sigma_{\mathrm{S} / \mathrm{W}}=\sigma_{\mathrm{O} / \mathrm{w}} \cos \theta
$$

where:

$\sigma_{\mathrm{S} / \mathrm{O}}=$ interfacial tension between solid and oil

$\sigma_{\mathrm{S} / \mathrm{w}}=$ interfacial tension between solid and water

$\sigma_{\mathrm{O} / \mathrm{w}}=$ interfacial tension between oil and water

$\theta=$ contact angle

The fact that $\sigma_{\mathrm{O} / \mathrm{w}} \cos \theta$ is not a constant value, but rather a function of $\mathrm{pH}$, means that $\left(\sigma_{\mathrm{S} / \mathrm{o}}-\sigma_{\mathrm{S} / \mathrm{w}}\right)$ is also a function of $\mathrm{pH}$. It is mathematically possible to have changes in oil-water interfacial tension, $\sigma_{\mathrm{O} / \mathrm{w}}$, and contact angle, $\theta$, such that the product $\sigma_{\mathrm{O} / \mathrm{w}} \cos \theta$ will remain constant. If that is the case, the value of $\left(\sigma_{\mathrm{S} / \mathrm{O}}-\sigma_{\mathrm{S} / \mathrm{w}}\right)$ will remain constant. If the surface effect at the oil/solid interface will not be a function of the $\mathrm{pH}$ of the water used, the dependence of $\left(\sigma_{\mathrm{S} / \mathrm{O}}-\sigma_{\mathrm{S} / \mathrm{w}}\right)$ upon $\mathrm{pH}$ can then be related only to the changes in $\sigma_{\mathrm{S} / \mathrm{w}}$. No solid information is available about the dependence of $\sigma_{\mathrm{S} / \mathrm{w}}$ upon $\mathrm{pH}$; however, the following analysis is suggested.

Since water is a polar compound (i.e., each of its molecules possesses a net positive charge on one side of the molecule and a net negative charge on the other side), its adhesive forces (due to electrostatic attraction) with the solid surface will be higher, the higher the charge the higher the adhesive force on that surface. Since the negative charge on sand surface increases, and consequently $\sigma_{\mathrm{S} / \mathrm{w}}$ decreases (i.e., $\theta$ decreases from Eq. (1)) with $\mathrm{pH}$, it is expected to have an increase in the absolute value of $\left(\sigma_{\mathrm{S} / \mathrm{o}}-\sigma_{\mathrm{S} / \mathrm{w}}\right)$ up to $\mathrm{pH} 10$ where sand surface attains its maximum negative charge. Over $\mathrm{pH}$ 10 , compression of the electric double layer occurs and the absolute value of zeta potential decreases. Consequently, $\sigma_{\mathrm{S} / \mathrm{w}}$ increases (i.e., $\theta$ increases from Eq. (1)).

Experiments with quartz show that quartz is strongly water-wet in pure $\mathrm{NaCl}$ solutions and become oil-wet when $\mathrm{NaOH}$ is added ${ }^{1)}$. These results confirm the results obtained in this investigation.

Figure 13 also shows that the contact angle was affected by $\mathrm{pH}$ in such a manner that the values of $\mathrm{pH}$ higher than 12 resulted in an abrupt increase in the contact angle. This may be due to the increase in reaction rate at higher values of $\mathrm{pH}$. Multivalent metal ions in the brine can reduce the solubility of the crude surfactants, helping to promote oil-wetting ${ }^{1)}$ (i.e., increasing the contact angle).

The results of contact angle measurements with the crude oils at $50^{\circ} \mathrm{C}$ are shown in Fig. 14. The contact angle increases with increasing $\mathrm{pH}$ for all crude oil used at $50^{\circ} \mathrm{C}$.
In this case, the hydroxide ions react with the organic acids in the crude oils producing surfaceactive agents that lower the interfacial tension and alter the wettability of the rock. At alkaline $\mathrm{pH}$, the alkali adsorbs on the rock and makes the surface oil-wet. In addition, asphaltenes may deposit on the rock and promote making the rock oil-wet conditions at the higher temperature, $50^{\circ} \mathrm{C}$.

A change in the molecular nature of the surface of the solid phase (e.g. owing to adsorption of the surface active components of oil due to increase in temperature) may result in a change in the value and even the sign of the contact angle; hence the disappearance of the minimum at $50^{\circ} \mathrm{C}$ as shown in Fig. 14.

\section{3 Effect of Temperature on Wettability}

Anderson ${ }^{1)}$ in his recent series of review papers reported that changing the temperature tends to make a core more water-wet at higher temperatures. This behavior was attributed to the increase in the solubility of wettability-altering compounds by increasing temperature. This confirmed the results obtained in the present investigation when distilled water was used for all crudes as shown in Figs. 3 and 7.

As seen from the results obtained from the present investigation, increasing temperature tended to make the core oil-wet for all Saudi crude oils tested when $\mathrm{NaCl}$ and $\mathrm{NaOH}$ solutions were used as shown in Figs. 3 through 10, or in Figs. 11 and 12. This effect has not yet been reported in the literature. This may be explained qualitatively by sodium/hydrogen/weak-acid exchange with the reservoir rock as

$$
\mathrm{MH}+\mathrm{NaOH} \longrightarrow \mathrm{MNa}+\mathrm{H}_{2} \mathrm{O}
$$

where, $\mathrm{MH}$ is the ionizable surface acid groups.

This Eq. (2) implies that sodium/hydrogen ion exchange would quantitatively obey a Langmuir isotherm. Likewise Bunge ${ }^{20}$ ) demonstrates that the mass action equilibrium of the above equation can reflect increased hydroxyl uptake at higher temperatures. On the other hand, sand (silica) is reacting with alkaline chemicals, and the reactions could be represented by the following Eq. (3):

$$
\begin{aligned}
\text { Caustic }+ \text { sand } \longrightarrow \\
\text { soluble silica }+ \text { insoluble mineral }
\end{aligned}
$$

This reaction involves the formation of soluble silica. The presence of silica ions will tend to retard the chemical reaction. This behavior may also be due to the wettability altering compounds of the crude that will adsorb on the surface at the higher temperature, $50^{\circ} \mathrm{C}$. 
Compression of the electric double layer is higher in the presence of $\mathrm{NaOH}$ and $\mathrm{NaCl}$ than in the prsence of $\mathrm{NaCl}$ alone. The higher the compression of the electric double layer, the smaller is the absolute zeta potential, and consequently the higher is $\sigma_{\mathrm{S} / \mathrm{w}}$ (i.e. the higher is $\theta$ ).

The effect of pressure was not studied in this work. A previous study, however, showed that pressure is much less important than temperature ${ }^{21)}$

\section{Conclusions}

Based on the results obtained in this investigation, the following conclusions can be drawn:

1) Contact angle increased with increasing Saudi Crude oil acidity at both 22 and $50^{\circ} \mathrm{C}$ for all $\mathrm{NaOH}$ concentrations used.

2) Contact angle tends to decrease with increasing $\mathrm{pH}$, up to $\mathrm{pH} \mathrm{10}$; thereafter, it shows an increase with further increase in contact angle at $22^{\circ} \mathrm{C}$.

3) For all $\mathrm{pH}$ values of the aqueous phase used, increasing the $\mathrm{pH}$ increased the contact angle at $50^{\circ} \mathrm{C}$ for all crude oils (no minimum was found in this case).

4) The Saudi crude oil/brine/rock system was found to be more oil-wet at $50^{\circ} \mathrm{C}$ when using $\mathrm{NaCl}$ and $\mathrm{NaOH}$ solutions.

5) The contact angle decreased as the temperature increased from 22 to $50^{\circ} \mathrm{C}$ when distilled water was used. Adding $\mathrm{NaCl}$ and $\mathrm{NaOH}$ to distilled water, the contact angle increased as the temperature was increased.

\section{References}

1) Anderson, W. G., Journal of Petroleum Technology, October, 1125 (1986).

2) Seifert, W. K., Howells, W. G., Anal. Chem., 41, (4), 554 (1969).

3) Cram, P. J., "Wettability studies with non-hydrocarbon constituents of crude oil", Petroleum Recovery Research Inst., Research Report PR-17 (Dec. 1972).

4) Johnson, R. T., Dunning, H. N., Producers Monthly, 23, (1), 20 (1959).

5) Donaldson, E. C., Am. Chem. Soc., Div. Petrol. Chem., 26 , (1), 110 (1981).

6) Denekas, M. O., Mattax, C. C., Davis, G. T., Trans., AIME, 216, 330 (1959).

7) Donaldson, E. C., Chilingrianl, G. V., Yen, T. F., "Enhanced oil recovery, I Fundamentals and analysis," Elsevier, Amsterdam (1985).

8) Sayyouh, M. H., Dahab, A. S., Omar, A. E., J. Petrol. Sci. Eng., 12, (1), (1990).

9) Anderson, W. G., J. Petrol. Tech., 1986, 1246.

10) Anderson, W. G., J. Petrol. Tech., 1986, 1371.

11) Anderson, W. G., J. Petrol. Tech., 1987.

12) Anderson, W. G., J. Petrol. Tech., 1987, 1453.

13) Anderson, W. G., J. Petrol. Tech., 1987, 1605.

14) Cuiec, L. E., 50th Annual Fall Meeting of SPE of AIME, Texas, Sept. 28-Oct. 1, 1975, SPE 5634.

15) Cuiec, L. E., Longeron, D., Pacsirszky, J., Middle East Oil Technical Conference of SPE, Bahrain, March 1979, SPE 7785.

16) Cuiec, L. E., 59th Technical Conference of SPE, Texas, Sept. 1984, SPE 13211.

17) McCoffery, F. G., J. Cdn. Pet. Tech., 1972, July-Sept.

18) Institute of Petroleum, "Standard methods for testing petroleum and its products", (1948).

19) Trieber, L. E., Archer, D. L., Owens, W. W., SPE J., 1972 531.

20) Somerton, W. W., Radke, C. J., JPT, 1983, March.

21) Hjelmeland, O. S., Larrondo, L. E., SPE J., 1986, 321.

要 旨

\title{
中東原油-塩水一砂岩間の相互作用がぬれ性に与える影皟
}

\author{
M. H. Sayyouh and M. Al-Blehed
}

Petroleum Engineering Dept., King Saud University, P. O. Box 800, Riyadh 11421, Kingdom of Saudi Arabia

\footnotetext{
本研究は, 5 種類のサウジ原油についてサウジ砂岩に対する 机性を検討することを目的として行った。これら原油の酸性 度を測定し，酸性度，アルカリ性度および温度がぬれ性に与え る影響について検討した。実験したすべての $\mathrm{NaOH}$ 濃度に対 し， $22^{\circ} \mathrm{C}$ および $50^{\circ} \mathrm{C}$ の双方において，またすべてのサウジ 原油において，その酸性度とともに接触角は増加した。 $22^{\circ} \mathrm{C}$
}

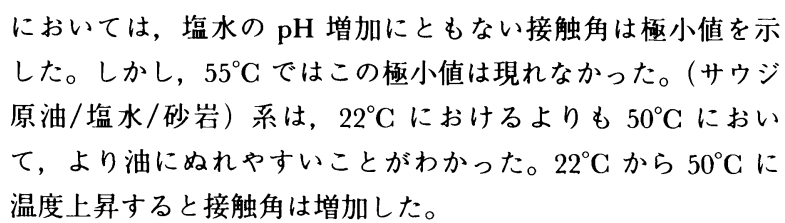

温度上昇すると接触角は増加した。

Keywords

Wettability, Acidity, Alkalinity, Contact angle, Crude oil 